Salvatore Costanza

\title{
Voices, Hearing and Acoustic Epiphany in Nonnus' Paraphrase of St. John's Gospel
}

At first, if we consider Nonnus' paraphrastic poem, we can state that the appearance of the Lord as a perennial theophany countermarks his epic devoted to a learned audience, which is comprised of Christians and not-Christians alike. ${ }^{1}$ Hexameter rewriting of the Fourth Gospel relates to the outstanding interactionist process between Hellenism, not to be merely likened to 'paganism' and Christianity deeply engaged with Greek paideia. ${ }^{2}$

As far as it concerns epiphanic signs, this Christian poem deals with the prophetic power of the voice of Christ as an eminent proof of his divinity revealed to his witnesses. ${ }^{3}$ The discovery of Jesus' divine presence is not restricted to visual signs, such as beauty, brightness and radiance, which are traditionally attached to divine epiphany since Homeric epics. ${ }^{4}$ These signs are likewise linked with the nearness of Jesus in Nonnus' Paraphrase. ${ }^{5}$ Beyond any doubt, Nonnian light symbolism widely develops the idea of the Saviour as the $\varphi \omega \sigma \tau \eta \dot{\rho}$, which enlightens the world by giving illumination to his disciples. ${ }^{6}$ Apart from explanations about light upon Gnostic sources, $^{7}$ the Paraphrast, here, follows Alexandrian theology, especially Cyril's teachings. ${ }^{8}$

1 On cultivated readers and/or listeneres of Nonnus' epics, see Agosti (2001) 97-99; Id. (2005); Id. (2009) 332; Whitby (2016) 216; Franchi (2016) 247.

2 On this intercultural meeting, see Dijkstra (2016) 83-84 with the status quaestionis of Nonnian studies. The use of Homeric topoi beside models drawn from Christian poetry is very common, not only in Gregory of Nazianzus and Nonnus, but also in epigraphic poems of the $4^{\text {th }}$ and $5^{\text {th }}$ centuries, see Agosti (2010) 329-330, 347-349; Id. (2016).

3 For epiphany as an arising phenomenon in the Graeco-Roman world, see Pfister (1924) 314-317, Pax (1955) 30, 109, 144; Gladigow (1990); Versnel (1987); Id. (2016) 37-43; Graf (1997), Id. (2004). On New Testament epiphany motives, see Frenschkowski (1995) 9-20; Id. (1997); Mitchell (2004) $183-187$.

4 See Pfister (1924) 316; Beierwaltes (1957) 14-23; Pax (1962) 842; Bremer (1975) 1-12; Gladigow (1990), 98-100; Graf (1997) 1151; Bierl (2004) 51; Bravo (2004) 66-67; Versnel (2011) 38; Id. (2016) 38 with nt. 50, 60 .

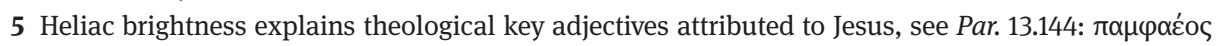
Xрıбтоĩo, with an Orphic ambience, see Greco (2004) 168 ad loc., with Homeric, Classical and postClassical parallels. Among them, similarities of Orphic poetry are very relevant, see Orph. H. $6.5 \pi \alpha \mu-$

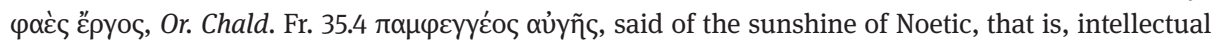
light. In Latin Poetry Iuvencus puts particular emphasis on light symbolism, see Röttger (1996) $80-91$.

6 See Filoramo (1980) 28-42; Id. (1982) 868-880; Zoroddu (1994) 231-232; Thomassen (2004) 222224.

7 For Jesus' self-identification with the Light, see Johnson (2016) 273; Sieber (2016) 314 with reference to the Logos in the Par. See Zöckler (1999) 127; Popkes (2004) 654-655; Id. (2005) 541 with nt. 83; Id. 
Christ healing the man born blind is defined as a light-bringer ( $\left.\varphi \alpha \varepsilon \sigma \varphi \rho_{\rho} \rho \varsigma\right)$ in Par. IX.28. ${ }^{9}$ Similarly, Nonnus puts great emphasis on the restoration of light at the Raising of Lazarus. This healing also establishes the identity between light and life. ${ }^{10}$ The language of sunlight in the Paraphrase is closely linked with the divine mission of Jesus as heavenly Saviour, ${ }^{11}$ as well as with the opposition between the darkness of sins and the dawn of his redemption. ${ }^{12}$

As relevant as visual aspects may be, they are, however, not the only ones involved in epiphany according to a longdating tradition. Greek religious experience also puts emphasis on acoustic signs revealing the divine presence. It often happens that the listener recognizes a superhuman voice that addresses him through a numinous message and/or an order to be promptly executed. ${ }^{13}$ Starting from Homeric epics until Neoplatonic teaching, auditory revelations are focused on instructions,

(2007) 137; Onuki (2008) 297-299, 303, 307-317 with theological relation to the Gospel of Thomas and Manichaean dualism between Light and darkness.

8 See Livrea (2000) 155, with reference to Cyril's theology in his commentary to Johannine logion

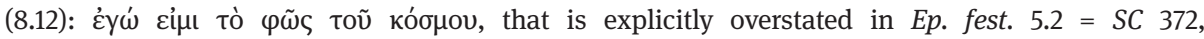
288.40 - 42. Évieux-Burns. In Alexandrinian realm, see also Clem. Alex. Strom. 1.28.178: oủk ővev

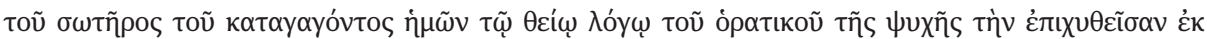

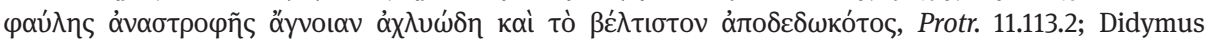
Caec. De Trin. $P G 39.728$.

9 See Johnson (2016) 273-274: Nonnus puts emphasis on material elements such as clay and water

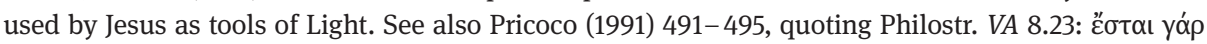

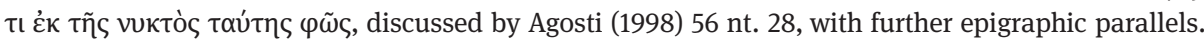
On Homeric antecedent of Odysseus who brought light into the house and the polis, see Bremer (1976) $150-160$ discussed by Birl (2004) 56, who points out the Odyssey, as "an extremely protracted performance of an epiphany of is main hero". Isillus portrays the Pagan Healer god, Asclepius, as "gleaming with golden armament" in an epigraphic hymn set up in Epidaurus, where he describes

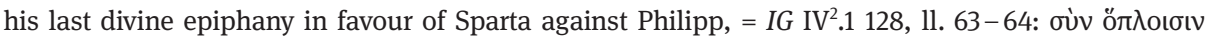

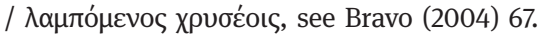

10 On the comparison between miracle reports in Par. 9 and 11, see Spanoudakis (2014) 88-90: the close association of these episodes is operative in art representations and theological contemporary debate. In Dion. 25, Dionysus heals an Indian born blind before enacting the resurrection of Tylus. 11 The healing of the blind man in Par. 9 is explained as a rebirth of a child emerging from the womb. Hence, the emphasis on the dawn as birth-panged (9.158: ноуобтóко૬) and unbeheld (9.178: $\dot{\alpha} \theta \eta \dot{\eta} \tau o \varsigma)$ underlies the idea of salvation given through revelation, which "in Nonnus' vision is both creation and illumination”, as Franchi (2016) 260 remarks; see also Spanoudakis (2014) 91; Johnson (2016) 275 on the imagery of light as a mediumistic way of access to Jesus' self-revelation.

12 See Par. 1.20 - 27a. See Platt (2009) 154; Ead. (2011) 11; Whitaker (2015) 55- 58 on Johannine model of spiritual blindness needing the illumination given by Jesus; Bennema (2014) 253-255. On Christ as Sol salutis, see Dölger (1925); Agosti (1998) 55-57; Greco (2004) 111; Spanoudakis (2014) 179 on Par. XI.34a.

13 On Wortepiphanie, see Pax (1955) 20, 35; Id. (1962) 20, 30; Dodds (1959) 140; Benz (1969) 94-97, 150, 413 - 440; Speyer (1972) 340; Id. (1991) 288; Id. (1994) 18 - 20; Id. (1995) 75-95, Id. (2007) 91; Hanson (1980) 1411; Casadio (1989) 141; Dulaey (1989) 379 (vision auditive); Frenschkowski (1995) 195, 197, 220; Weber (2000) 42. 
teachings, or prophecies. ${ }^{14}$ Notoriously, Gnostic doctrine is mostly related to heavenly voices. Marcos, a chief teacher of Valentinian School in Rome, was claiming to receive complex revelations by the voices of Pleromatic hypostases that he would have heard without seeing any superior being. This modus apparendi corresponds to usual didactic epiphany among the Gnostics. ${ }^{15}$

The lore of magic also focuses on the revelation of true names of gods unknown to the uninitiated through special acoustic sounds. Thus, the magical name Batv $\chi \omega$ $\omega \omega \chi$ that expresses the hidden name of the highest god is based upon the prolonged sound of /o:/. ${ }^{16}$ Phonetic association, alliteration (/r/, /vr/, /t/), repetition and various other sound plays are widely exploited in Graeco-Egyptian magical papyri for these purposes. ${ }^{17}$

In the Graeco-Roman world, the spoken word quickly gained the significance of a fatal voice: the god choses a human speaker as his medium in order to reveal hidden truths. Therefore, the $\kappa \lambda \eta \delta \omega \dot{v}$ as chance voice was conceived as embodying a presage of future events, the epithet $\kappa \lambda \eta \delta \omega$ vios (producing an ominous voice) is attributed to Zeus. A personified divine voice, as $\Phi \eta$ n spired a crowd of people by creating mutual feelings to everyone of them. ${ }^{18}$ Many examples of panic running through armies or assemblies because of mysteriously heard voices also come from the realm of Greek war. ${ }^{19}$ Words overheard accidentally were often interpreted as prophetic omens. The revelation was originated by single words or a complete phrase, a carelessly pronounced utterance was listened by somebody else in a wholly fortuitous and unexpected manner. The listener just simply had to link such word(s) through mental association to some plane, project, or event of particular importance for his personal destiny. ${ }^{20}$ All these omens employed the human word as an outgoing presage. Therefore, a word's divination like cledonism was closely associated to Hermes, the divine Master of the Logos. ${ }^{21}$ If the children pronounced the fateful saying without being in any relation to the listener, they were

14 See Roloff (1970) 48-49 on Homeric heroes hearing godly voice; Procl. In Crat. 36.20; Hippol. Ref. 4.28 knows of tricks drawn by manipulating divine auditions, see Dodds (1959) 366 with nt. 3. 15 Marcos' teaching is a matter of a mystical doctrine about letters and numbers learned through revealing speeches, such as Derdekeas experiences in his teaching transmitted in the Paraphrase of Sem, see Casadio (1989) 126-127, 142.

16 In PGM IV 1. 936, the magician prescribes to hold the numerical value of 3663 on a leaf of papyrus, in order to pray the mystical name of Baıv $\omega \omega \omega \chi$ quoted at 1. 1057, see Brashear (1989), 123-124.

17 On these key issues of Ancient ritual experience, see Crippa (2015) 245-249.

18 Scholia to Iliad VIII.250; Eustathios 169.27. Denominative verb $\kappa \lambda \eta \delta o v i \zeta \omega$ is found in P. Oxy. VI 886 (= PGM XXIVa) 1l. 13-15, $3^{\text {rd }}$ century $^{\mathrm{p}}$ also means 'to receive an omen'. For the Ancient idea of $\Phi \eta \dot{\mu \eta}$ linked with divination by casual words, see Pritchett (1979) 132, 134-135; Crippa (2012) 550-553. 19 For military examples of chance voices in topic moments, see passages discussed by Pritchett (1979) 133-134, 137; Lateiner (2005).

20 See Hopfner (1928) 1282-1283; Riess (1939) 373-376; Peradotto (1969) 8. As Johnston (2008) 131 puts out, "unexpected" is the key-word for this method of approaching the supernatural sphere. 21 See Peradotto (1969) 9; Johnston (2008) 100. 
regarded as the most truthful ones. ${ }^{22}$ The most famous example in Christian milieu is the tolle et lege heard by Augustine. ${ }^{23}$

All of this ascertained, acoustic revelation is worthy of further examination in this Nonniam poem. With respect to Biblical parallels, it would be a simplistic approach to overstate auditory elements in Old Testament epiphany, while to assign a major role to New Testament visual signs in accordance with typical Hellenistic and Late Antique trends. ${ }^{24}$

In fact, visual and auditory elements are intertwined in the realm of godly revelation in the Old as well as in the New Testament. ${ }^{25}$ If we analyze Old Testament reports about self-perception, the mystical narrator mostly refers to an epiphanic encounter with the divine without any distinction between seeing and hearing. For example, the prophet Isaias simultaneously describes the vision of the Lord sitting upon the throne and the hearing of his voice before receiving a commission. ${ }^{26}$ Generally said, sensorial perceptions of seeing and hearing are interlinked in biblical epiphanic accounts. Similarly, Graeco-Roman thinkers were aware that seeing and hearing are in fact interchangeable as indicators of a revelation's superhuman encounter. This link clearly appears at the descent to the Trophonios' hole at Lebadeia in Boeotia. After a frightening catabasis into the hole meant with the hope of meeting the Chthonian hero, the enquirers were compelled to record everything they saw or heard. ${ }^{27}$

As far as concerns Nonnus' epiphany reports, we remark that they are deeply engaged in acoustic effects. At first, Jesus' voice provides an auditory sign of his revelation as Messiah. Therefore, Christ's word is defined as Life-giving ( $\beta\llcorner\delta \omega \dot{\tau} \tau \omega)$ ). This is observed under a key theological perspective in Par. X.133:

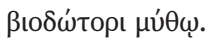

This adjective (and its alternative form $\beta ı \delta \delta \tilde{\omega} \tau \iota)$ ) is a standardized epithet used in Orphic Hymns. It has many Late Antique parallels, often with reference to traditional deities of a politheistic pantheon. In this respect, an epigraphic sentence concerning

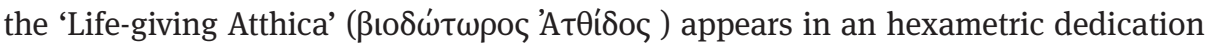

22 For children considered as ominous speakers among the Egyptians, see Plutarch., De Is. et Os. 14; Athen. 8.8; Hopfner (1928b) 1277; 1279; Peradotto (1969) 4 with n. 8; Somville (1989) 202-204; Montero (1999) 291.

23 See Aug. Conf. VIII.12.29, Dulaey (1989), 379, 384, 389, see also Benz (1969), 95; Giannarelli (1989), 234. On children as privileged medium of divine revelation, see Courcelle (1953), 194-220; Johnston (2001), 97-99.

24 See Björck (1946) 306-310; Pax (1955) 20, 110 -111; Balthasar (1968) I, 261-262.

25 See Moreira (2000) 18 with nt. 15.

26 Is 6.1-8, see Pax (1955) 110; Déonna (1965) 62; Benz (1969) 98-99, 418 on the Zusammenspiel of sensorial perceptions; Speyer (1972) 340; Agosti (2003) 378-379.

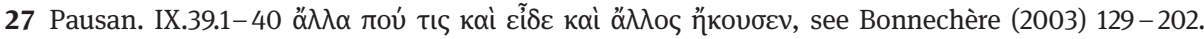


of late $4^{\text {th }}$ - early $5^{\text {th }}$ century given by the proconsul Phaedrus, in order to celebrate his restoration of Dionysos' theatre in Athens. ${ }^{28}$

Subsequently, Jesus' voice is the first way of access to salvation. It is people-sav-

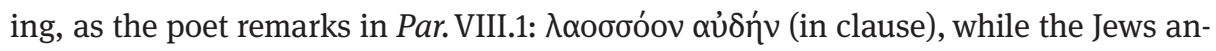

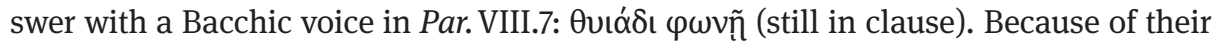
spiritual blindness, they cannot but shout nonsensical words in reply to the divinely inspired word of the Saviour. ${ }^{29}$

Superhuman force is expressly attributed to the Voice of the Lord in reply to Peter at the washing of the feet in Par. XIII.30:

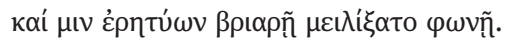

Here, the poet uses the pregnant adjective ßpıарó in order to focus on strenght of divine Jesus' utterance.

Likewise, he says for Jesus speaking to Annah in Par. XVIII.95-96:

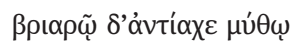

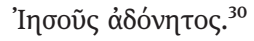

There is further evidence for epiphany as auditory revelation. Divine proximity is evidenced through Christ's liberating voice in the healing of the paralyzed man accounted in Par. V. At first, the Lord consoles the poor man through his voice that can breathe new life at v. 29:

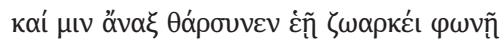

The key adjective $\zeta \omega \alpha \rho \kappa n ́ \varsigma^{31}$ probably echoes a Proclus' passage (H. 1.2) in praise of the Sunlight, where the role of Helios as creator of all things is described, as Agosti has pointedly illustrated. ${ }^{32}$

Then, the Lord suddenly healed the paralyzed man through his word releasing grief at v. 37:

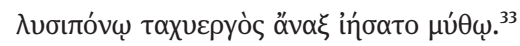

$28 I G^{I I} 5021$ discussed by Agosti (2010) 347.

29 On the theological significance of properties enounced for the Word, see Sieber (2016) 313. On the blame against Jews, see Livrea (2000) 234-235 on Par. II.58.

30 As Livrea (1989) 156 pointed out; see also Greco (2004) 95.

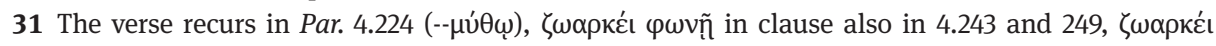
$\mu v \dot{\theta} \omega$ even in 15.32, 17.60 .

32 Proclus' locus similis was recognized by Schneider (1892) 599; see also Golega (1930) 102; Agosti (2003) 362-363 assigns chronological priority to Proclus or alternatively to a common model in Neoplatonic writings. See parallels in the Par. and Ancient Christian literature quoted ibid.

33 See Agosti (2003) 378-379 ad loc. 
In this respect, Christ is focused as a clear counterpart for Dionysos who is equally portrayed as a celestial Healer through his Bacchic voice. Nonnus describes the 'pagan' god exercising his healing power in favour of Aristeus in Dion. XVII.373:

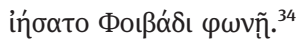

Christ in turn bestows the Resurrection of the flesh through his Word of Life in Par. V.110:

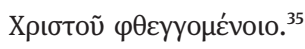

A close association of revealing through vision and hearing is experienced at the first appearance of Jesus in the poem. Two disciples near to John the Forerunner and the Lord are still unaware of the divine nature of the latter in Par. I.129b-130:

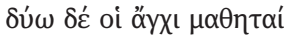

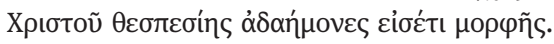

In the following, the epiphanic experience is fulfilled first through the holy word of John as the true witness, as it is remarked in I.135:

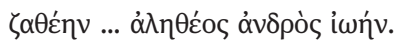

Here, John the Baptist's utterance arises to the highest witness of the divine Logos. In

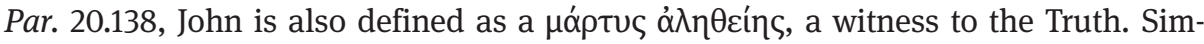

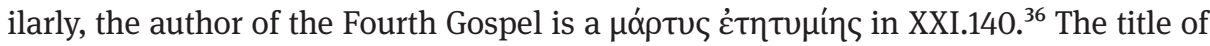
martys is, here, subsumed as a technical word for the true witness who announces the forthcoming of the Messiah after having personally experienced the meeting with him. ${ }^{37}$

Jesus himself gives the value of true witness to his prophetic words at the last supper in Par. XIII.85-89:

34 Passage quoted by Agosti (2003) 379-380 with further loci similes relating to the healing power of Dionysus, who is an evident counterpart for Christ. Both gods enact a cathartic power exercised in favour of their elected. On healing by magic lullabies in Nonnus' 'pagan' poem, see Gigli (1985) 221-223 with further parallels.

35 On Theurgic power of Christ's voice, see Agosti (2003) 140, 478 ad loc.; Rotondo (2008) 298-302. 36 Ebener (1985) 406 and Sherry (1991) 276 wrongly refer this title to Jesus. On the value of the Fourth Gospel's last chapter, see Sherri 2015.

37 Therefore, the Baptist is defined as a martys and John the Evangelist alike, see Vian (1997) 145; 150 - 154 with further examples about Nonnus' special love for this semantic family; see also Accorinti (1996) 228 on XX.138. 


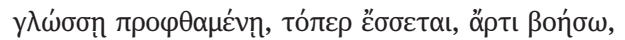

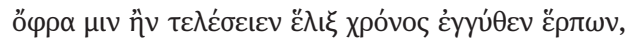

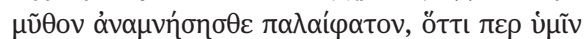

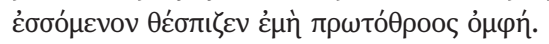

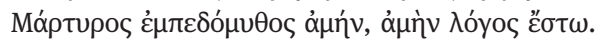

The solemn address to the apostles is built around the notion of a prophetic, arcane voice, that carries great significance and discovers hidden meanings. There is relevance in the use of words borrowed from the oracular vocabulary of divination like $\theta \varepsilon \sigma \pi i \zeta \omega$ and ỏ $\mu \varphi \eta$ at the same verse (XIII.89). All these remarks convey a superhuman value to the Christ's voice according to a theophanic dimension, the divinity of the truthful Teacher being disclosed to his listeners. ${ }^{38}$

The key idea of the true witness plays a major role in the Paraphrase. It is linked with a conceptual mode concerning the person of Christ. As the author of Apc 3.14.

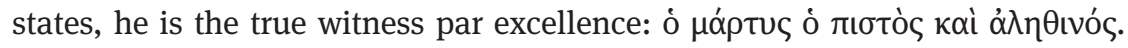

If we analyze the first meeting between the disciples of the Baptist and Jesus, sound and visual effects are intertwined, so as to allow the access to the divinity

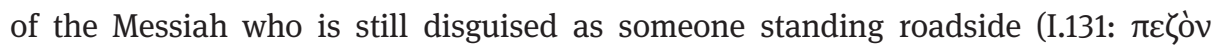
ósítnv).

In the first encounter with Jesus in Par. 1, the two disciples are finally overcome by the godly gaze of Christ, which is defined as being self-learned (I.137: $\alpha$ vito $\delta i \delta \alpha-$

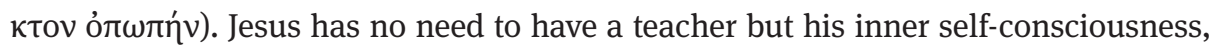
as his gnosis has nothing to do with human knowledge that can be learned. However, revelation of divine presence is accompanied by authoritative words which are intimately connected with the vocation of the apostles.

Similarly, the miracle of Jesus in Par. VI.4 is enacted through his Word, even if it has a visual form for the observers:

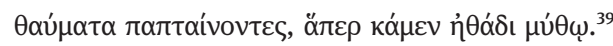

In Par. XXI, the dialogue between the Risen Lord and Peter corresponds with a postResurrection appearance accounted under an ecclesiological perspective. Specifically, Peter is asked three times: "Do thou love me?" (vv. 83-107). This triple question focuses on his three-part denial previously accounted in Par. XVIII.70-129.40 Jesus had already prophesied of Peter's denial until the cockcrows at the end of XIII.158-160: ${ }^{41}$

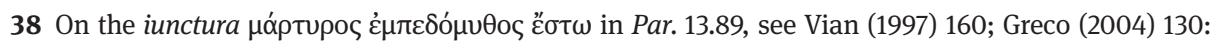
this formula was created by Nonnus for his Christian poem and later introduced in Dion.

39 On people observing the miracle performed through Jesus' usual word, see Franchi (2013) 278. 40 See Livrea (1989) 143-153, 167-173; Costanza (2014) 136-137. Generally, the first place in Apostle's catalogues of the New Testament is always reserved to Peter, as Greco (2004) 91 remarks.

41 See Greco (2004) 174-176. 


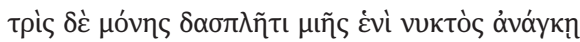

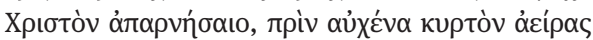

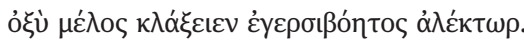

Here, the first cockcrow is to be explained as another acoustic sign relating to epiphany, because the cockerel is a clear symbol of Christ. ${ }^{42}$ Nonnus paraphrases his Vorlage with consistent embroidery. His abundant adjectival use at v. 160 is far from

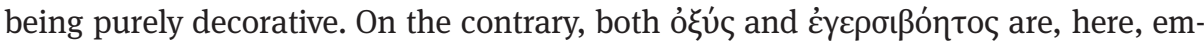
ployed on the grounds of exegetical undertones.

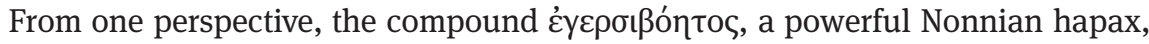
refers to a spiritual soul's awakening according to a major initiatory trend of Late Antique religion, especially in Orphic milieu..$^{43}$ In contrast, the cockcrow is described as a high song in Dion. XI.89:

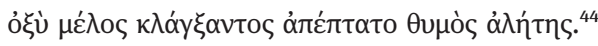

Symbolically, the image of the cockerel crowing in Par. XIII is referred to the voice of Christ himself following the exegetical explanations given by Cyril of Alexandria:

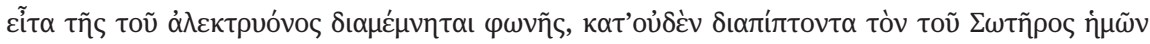

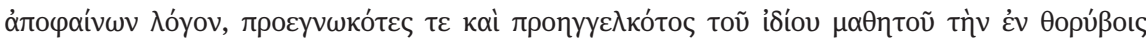

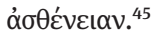

Ultimately, Peter may receive his full investiture at the head of the apostolic group and also of the herd of believers in the course of Jesus' last appearance after his Resurrection in Par. 21. Indeed, this investiture is conferred upon him just after he has duly performed his profession of faith by speaking aloud with his Teacher in a dramatic verbal contest. This contest in which Peter is involved is comparable to that of Pallene in the last song of the either Nonnian epic. Both heroes are fighting with the god and reach him after diving into water. If Pallene is engaged with a hard physical fight against Dionysos, Peter must counterbalance the divine words of his Lord. ${ }^{46}$

Finally, the Word of Christ in Nonnus' poem is not only convincing in rhetorical terms, but also revealing about God's presence to the cosmos awaiting its Redeemer. All these things considered, epiphanic issues in Par. renew a complex intertextual framework, in which auditory elements undeniably play a major role within a history

42 On Christian soteriologic idea, see Pintus (1985-86) 262-266.

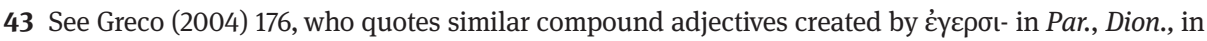
Proclus and Orphic milieu. These adjectives express the soul's awakening.

44 See Cyril 609a, as Livrea (1989) 172-173 remarks with further parallels for the cockcrow; Greco (2004) $175-176$.

45 Indeed, Nonnus does not further develop the cockerel's symbolism in Par. 18.129, in order to keep the brevity of Gospel's narrative, see Livrea (1989) 173.

46 For Pallene in Dion. 48.118-120, cf. Par. 21.41-42; see Costanza (2014), 125. 
of multiform and disguise. Beyond any doubt, the Paraphrast overlooks Biblical exegesis and Greek poetry relating to the access to the divine. At the same time, he is able to adapt his narrative concerning theophany to many settings. Nonnus carefully establishes the necessity of auditory revelation as a source of theological knowledge, not merely because it helps humans to understand the truth of Christian faith, but because it is a privileged source of discovering the mysteries of the numinous upper world.

As a follower of Greek epic tradition, the poet is conscious of the mystical power of the Word and its great fascination. He could have exercised a stronger attraction to his listeners through his hexameters with their special subtle acoustics. Since his epics were reasonably destined to public performances, the voice of the poet echoes that of the heavenly Master and it is, subsequently, put at the service of the divine Revelation by conferring to it a special power of persuasion.

\section{Bibliography}

Accorinti (1996): Domenico Accorinti (ed.), Nonno di Panopoli. Parafrasi del Vangelo di S.

Giovanni. Canto XX (Pubblicazioni Cl. Lettere e Filosofia SNS Pisa 15), Pisa.

Accorinti (2016): Domenico Accorinti (ed.), Brill's Companion to Nonnus of Panopolis, Leiden and Boston.

Addey (2014): Crystal Addey. Divination and Theurgy in Neoplatonism. Oracles of the Gods (Ashgate Studies in Philosophy \& Theology in Late Antiquity), Farnham-Burlington/VT.

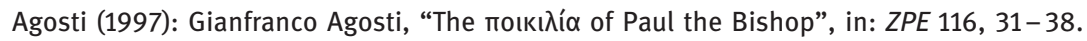

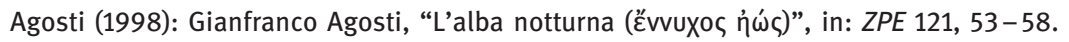

Agosti (2001): Gianfranco Agosti, “L'epica biblica nella tarda antichità greca. Autori e lettori nel IV e V secolo", in: Stella (ed.), 67-104.

Agosti (2003): Gianfranco Agosti (ed.), Nonno di Panopoli. Parafrasi del Vangelo di San Giovanni, Canto Quinto. Firenze.

Agosti (2005): Gianfranco Agosti, “Interpretazione omerica e creazione poetica nella Tarda

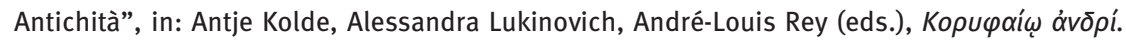
Mélanges A. Hurst, Geneva, 19-32.

Agosti (2006): Gianfranco Agosti, “La voce dei libri. Dimensioni performative dell'epica greca tardoantica”, in: Eugenio Amato, Alexandre Roduit, Martin Steinrück (eds.), Approches de la Troisième Sophistique. Hommages à Jacques Schamp, Brussel, 33-60.

Agosti (2009): Gianfranco Agosti, “Cristianizzazione della poesia greca e dialogo interculturale”, in: CrSt 31, 313-335.

Agosti (2010): Gianfranco Agosti, “Paideia” classica e fede religiosa: annotazioni sul linguaggio dei carmi epigrafici tardoantichi”, in: Cahiers du Centre Gustave Glotz 21, 329-353.

Agosti (2016): Gianfranco Agosti, “Les langues de l’épigramme épigraphique grecque : regards sur l'identité culturelle chrétienne dans l'Antiquité tardive”, in: E. Santin, L. Foschia (eds.), L'épigramme dans tous ses états: épigraphiques, littéraires, historiques, Lyon, 276-295.

Balthasar (1968): Hans Urs von Balthasar, La Gloire et la Croix: les aspects esthétiques de la Révélation, Paris.

Bannert (1978): Herbert Bannert, “Zur Vorgestalt der Götter bei Homer”, in: WS 12, 29-42.

Beierwaltes (1957): Werner Beierwaltes, Lux intelligibilis: Untersuchungen zur Lichtmetaphysik der Griechen, Munich. 
Bennema (2014²): Cornelis Bennema, Encountering Jesus. Character Studies in the Gospel of John, Minneapolis.

Benz (1969): Ernst Benz, Die Vision. Erfahrungsformen und Bilderwelt, Stuttgart.

Björck (1946): Gudmund Björck, “ővap íðعĩv. De la perception du rêve chez les anciens”, in: Eranos Jb. 44, 306-314.

Bonnechère (2003): Pierre Bonnechère, Trophonios de Lébadée. Cultes et mythes d'une cité béotienne au miroir de la mentalité antique (RGRW 150), Leiden.

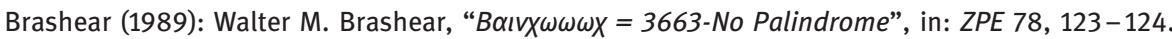

Bravo (2004): Jorge Bravo, "Heroic Epiphanies: Narratives, Visual, and Cultic Contexts", in Marinatos (ed.), 63-84.

Bremer (1975): Dieter Bremer, "Die Epiphanie des Gottes in den homerischen Hymnen und Platons Gottesbegriff”, in: ZRGG 27, 1-21.

Bremer (1976): Dieter Bremer, Licht und Dunkel in der frühgriechischen Dichtung: Interpretationen zur Vorgeschichte der Lichtmetaphysik, Bonn.

Busine (2005): Aude Busine, Paroles d'Apollon. Pratiques et traditions oraculaires dans l'Antiquité tardive (ii ${ }^{e}$-vi $i^{e}$ siècles), RGRW 156, Leiden-Boston.

Cadau (2015): Cosetta Cadau, Studies in Colluthus' Abduction of Helen. Mnem. Suppl. 380, Leiden-Boston.

Casadio (1989): Giovanni Casadio, "La visione in Marco il Mago e nella gnosi di tipo sethiano", in: Augustinianum 29, 123-146.

Clinton (2004): Kevin Clinton, “Epiphany in the Eleusinian Mysteries”, in: Marinatos (ed.), 85-109.

Costanza (2014): Salvatore Costanza, "La vestizione di S. Pietro (Nonno, Parafrasi 21, 37-48): paralleli nelle Dionisiache e significati simbolici”, in: Koinonia 38, 119-140.

Costanza (2017): Salvatore Costanza, "Le catalogue des Apôtres à la pêche miraculeuse: Nonn., par. xxı, EvPt 14.60”, in: Claude Bernard-Valette, Jérémie Delmulle, Camille Gerzaguet (eds.), Nihil veritas erubescit. Mélanges offerts à Paul Mattei par ses élèves, collegues et amis (IPM 74), Turnhout, 511-525.

Courcelle (1953): Pierre Courcelle, “L’enfant et les 'sorts bibliques”, in: Vig. Chr. 7, 194-220.

Crippa (2012): Sabina Crippa, "Entre la nature et le rite: reflexions sur le statut des signes, voix divinatoires”, in: Stella Georgoudi, Renée Koch Piettre, and Francis Schmidt (eds.), La Raison des signes. Présages, rites, destin dans les sociétés de la Méditerranée ancienne (RGRW 174), Leiden and Boston, 547-555.

Cutino (2009): Michele Cutino, "Structure de la composition et exégèse dans la Paraphrase de l'Évangile de s. Jean de Nonnos de Panopolis. Une lecture du chant III", in: RÉAP 55, $225-246$.

De Stefani (1999): Claudio De Stefani, “Nonniana”, in: Philol. 143.2, 336-343.

De Stefani (2002): Claudio De Stefani, ed. Nonno di Panopoli. Parafrasi del Vangelo di S. Giovanni Canto I (Eikasmos Studi 6), Bologna.

Dijkstra (2016): J. H. F. Dijkstra. The Religious Background of Nonnus, in: Accorinti (ed.), 75-90.

Dodds (1951): Eric R. Dodds, The Greeks and the Irrational, Berkeley-Los Angeles.

Dölger (1925): Franz Joseph Dölger, Sol Salutis, Münster.

Doroszewski (2014): Filip Doroszewski, “Judaic Orgies and Christ’s Bacchic Deeds: Dionysiac Terminology in Nonnus' Paraphrase of St. John's Gospel”, in: Spanoudakis (ed.), 287-301.

Dulaey (1989): Martine Dulaey, "Songe et prophétie dans les Confessions d'Augustin. Du rêve de Monique à la conversion au jardin de Milan", in: Augustinianum 29, 379-391.

Ebener (1985): Dietrich Ebener, Nonnos, II: Leben und Taten des Dionysios XXXIII-XLVIII. Nachdichtung des Johannesevangeliums, Berlin and Weimar.

Filoramo (1980): Giovanni Filoramo, Luce e gnosi. Saggio sull'illuminazione nello gnosticismo, Rome. 
Filoramo (1982): Giovanni Filoramo, “Phoster e Salvatore in alcuni testi gnostici”, in Ugo Bianchi and M. J. Vermaseren (eds.), La soteriologia dei culti orientali nell'impero romano, Leiden, $868-880$.

Filoramo (1989): Giovanni Filoramo, “Diventare Dio: visione e rigenerazione nello Gnosticismo”, Augustinianum 29, 81-121.

Franchi (2013): Roberta Franchi (ed.), Nonno di Panopoli, Parafrasi del Vangelo di San Giovanni. Canto sesto. Bologna.

Franchi (2016): Roberta Franchi, “Approaching the 'Spiritual Gospel': Nonnus as Interpreter of John”, in Domenico Accorinti (ed.), 240-266.

Frenschkowski (1995): Marco Frenschkowski, Offenbarung und Epiphanie. 1: Grundlagen des spätantiken und frühchristlichen Offenbarungsglaubens. WUNT, 2.79, Tübingen.

Frenschkowski (1997): Marco Frenschkowski, Offenbarung und Epiphanie. 2: Die verborgene Epiphanie in Spätantike und frühem Christentum. WUNT, 2.80, Tübingen.

Garcia (1999): Hugues Garcia, “La polymorphie du Christ. Remarques sur quelques définitions et sur des multiples enjeux", Apocrypha 10, 16-55.

Giannarelli (1989): Elena Giannarelli, “Sogni e visioni dell'infanzia nelle biografie dei Santi: fra tradizione classica e innovazione cristiana”, Aug. 29, 213-235.

Gigli (1985): Daria Gigli, Metafora e poetica in Nonno di Panopoli, Florence.

Gigli (1990): Daria Gigli, La cosmogonia di Strasburgo, Florence.

Gigli (1995): Daria Gigli, “Il pozzo di Giacobbe e Danao in Nonno”, in: Koinonia 19, 153-161.

Gladigow (1990): Burkhard Gladigow, “Epiphanie, Statuette, Kultbild, Griechische

Gottesvorstellungen im Wechsel von Kontext und Medium”, in: Visible Religion 7, 98-121.

Golega (1930): Joseph Golega, Studien über die Evangeliendichtung des Nonnos von Panopolis. Ein Beitrag zur Geschichte der Bibeldichtung im Altertum, Breslau.

Graf (1997): Fritz Graf, “Epiphanie”, in: Neue Pauly 3, 1150-52.

Graf (2004): Fritz Graf, “Trick or treat? On collective epiphanies in antiquity”, in: Marinatos (ed.), $111-130$.

Greco (2004): Claudia Greco (ed.), Nonno di Panopoli. Parafrasi del Vangelo di S. Giovanni, Canto tredicesimo, (Hellenica 12), Alessandria.

Hanson (1980): John S. Hanson, "Dreams and Visions in the Graeco-Roman World and Early Christianity", in: ANRW 2, 23, 2, 1395-1427.

Heinsdorff (2003): Cornel Heinsdorff, Christus, Nikodemus und die Samariterin bei Juvencus. Mit einem Anhang zur Lateinischen Evangelienvorlage (Untersuchungen zur antiken Literatur und Geschichte 67), Berlin-New York.

Hopfner (1928): Theodor Hopfner, “Mantike”, in: RE 14.1, 1258-87.

James (1981): A. W. James, "Night and Day in the Epic Narrative of Nonnus and Others", in: Mus. Phil. Lond. 4, 115-143.

Johnson (2016): S. F. Johnson, Nonnus' Paraphrastic Technique: A Case Study of Self-Recognition in John 9, in Accorinti (ed.), 268-288.

Johnston (2001): Sarah Iles Johnston, "Charming Children: the Use of the Child in Ancient Divination", in: Arethusa 34.1, 97-117.

Johnston (2008): Sarah Iles Johnston, Ancient Greek Divination (Blackwell Ancient Religions), Malden/Ma. and Oxford.

Junod/Kaestli (1983): Eric Junod and Jean-Daniel Kaestli (eds.), Acta Iohannis, textus alii Commentarius, Indices, CC-SA 2, Turnhout.

Koschorke (1977): Klaus Koschorke, “Eine gnostische Pfingstpredigt: Zur Auseinandersetzung zwischen gnostischem und christlichem Christentum am Beispiel der, Epistula Petri ad Philippum“ (NHC VIII, 2)”, in: ZKTh 74, 323-343.

Lateiner (2005): Donald Lateiner, "Signifying Names and Other Ominous Accidental Utterances in Classical Historiography.” in: GRBS 45.1: 35-57. 
Livrea (1989): Enrico Livrea (ed.), Nonno di Panopoli. Parafrasi del Vangelo di S. Giovanni Canto XVIII, Naples.

Livrea (2000): Enrico Livrea (ed.), Parafrasi del Vangelo di San Giovanni: Canto B, Bologna.

Marinatos (2004): Nanno Marinatos, ed. Divine Epiphany in the Ancient World = ICS 29.

Ménard (1972): Jacques E. Ménard, Transfiguration et polymorphie chez Origène, in Epektasis. Mélanges patristiques offerts au cardinal J. Daniélou, Paris, 367-372.

Mitchell (2004): Margaret M. Mitchell, "Epiphanic Evolutions in Earliest Christianity", in Marinatos (ed.), 183-204.

Moreira (2000): Isabel Moreira, Dreams, visions, and Spiritual Authority in Merovingian Gaul, New York.

Moreschini (1973): Claudio Moreschini, "Luce e purificazione nella dottrina di Gregorio Nazianzeno", in: Augustinianum 13, 535-549.

Nock (1934): Arthur Darby Nock, “A Vision of Mandulis Aion”, in: HThR 27, 53-104 = Id. 1972, I, 357-400.

Nock (1972): Arthur Darby Nock, post. Essays on Religion and the Ancient World selected and edited with an Introduction, Bibliography of Nock's writings, and Indexes by Z. Stewart, I-II, Oxford.

Onuki (2008): Takashi Onuki, “Das Logion 77 des Thomasevangeliums und der gnostische Animismus", in: Jörg Frey, Enno Edzard Popkes and J. Schröter (eds.), Das Thomasevangelium. Entstehung - Rezeption - Theologie, Berlin, 294-317.

Pax (1955): Elpidius Pax, EПIФANEIA. Ein religionsgeschichtlicher Beitrag zur biblischen Theologie (Münchener Theologische Studien, I Hist. Abt. 10), Munich.

Pax (1962): Elpidius Pax, "Epiphanie", in: RAC 5, 832-909.

Peradotto (1969): John Peradotto, “Cledonomancy in the Oresteia", in: AJPh 90, 1-21.

Pfister (1924): F. Pfister, “Epiphanie”, in: RE Suppl. 4, 277-323.

Pintus (1985-86): Giovanna Maria Pintus, “Storia di un simbolo: il gallo”, in: Sandalion 8-9, $243-267$.

van der Plas (1987): Dirk Van der Plas (ed.), Effigies Dei. Essays on the History of Religions (Suppl. Numen), Leiden.

Platt (2009): Verity Platt, "Virtual visions: Phantasia and the perception of the divine in the Life of Apollonius of Tyana”, in: E. L. Bowie and J. Elsner (eds.), Philostratus, Cambridge.

Platt (2011): Verity Platt, Facing the Gods: Epiphany and Representation in Graeco-Roman Art, Literatur and Religion. Greek culture in the Roman world, Cambridge.

Popkes (2004): Enno Edzard Popkes, "”Ich bin das Licht“ - Erwägungen zur Verhältnisbestimmung des Thomasevangeliums und der johanneischen Schriften anhand der Lichtmetaphorik”, in: Jörg Frey, Udo Schnelle, with J. Schlegel (eds.), Kontexte des Johannesevangeliums. Das vierte Evangelium in religions- und traditionsgeschichtlicher Perspektive (WUNT 175), Tübingen, 641-674.

Popkes (2005): Enno Edzard Popkes, “Die Umdeutung des Todes Jesu im koptischen Thomasevangelium”, in: Jörg Frey, Jens Schröter (eds.), Deutungen des Todes Jesu im Neuen Testament (WUNT 181), Tübingen, 513-545.

Popkes (2007): Enno Edzard Popkes, Das Menschenbild des Thomasevangeliums. Untersuchungen zu seiner religionsgeschichtlichen und chronologischen Einordnung (WUNT 206), Tübingen.

Prichett (1979): William Kendrick Pritchett, The Greek State at War, Part 3: Religion. Berkeley.

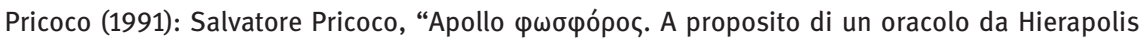
frigia", in: Studi di filologia classica in onore di Giusto Monaco, Palermo, 491-495.

Riess (1939): E. Riess, “Omen”, in: RE 18.1, 350-378.

Roloff (1970): Dietrich Roloff, Gottähnlichkeit, Vergöttlichung und Erhöhung zu seligem Leben. Untersuchung zur Herkunft der platonischen Angleichung an Gott (Untersuchung zur antiken Literatur und Geschichte 4), Berlin. 
Rotondo (2007): Arianna Rotondo, Dialogo d'amore. Figure femminili del Vangelo giovanneo (Appunti di teologia 11), Roma.

Rotondo (2008): Arianna Rotondo, “La voce ( $\varphi \omega v \eta ́)$ divina nella Parafrasi di Nonno di Panopoli”, in: Adamantius 14, 287-310.

Röttger (1996): W Röttger, Studien zur Lichtmotivik bei luvencus (JAChr. 24), Münster.

Schneider (1892): M. Schneider, "Die Hymnen des Proklos in ihrem Verhältnis zu Nonnos", in: Philol. 51, 593-601.

Sherri (2015): Brown Sherri, "What's in an Ending? John 21 and the Performative Force of an Epilogue”, in: Perspectives in Religious Studies 42, $29-42$.

Sherry (1991): L. F. Sherry, The Hexameter Paraphrase of St. John Attributed to Nonnus of Panopolis. Prolegomenon and Translation, Diss. Columbia University, New York.

Sieber (2016): Fabian Sieber, Nonnus' Christology, in: Accorinti (ed.), 308-326.

Somville (1989): Pierre Somville, "Jeux de mots et sense du sacré dans la religion grecque", in: Kernos 2, 199-211.

Spanoudakis (2014): Konstantinos Spanoudakis, ed. Nonnus of Panopolis. Paraphrasis of the Gospel of John XI. Oxford.

Spanoudakis (2016): Konstantinos Spanoudakis, Pagan Themes in the Paraphrase, in: Accorinti (ed.), 601-624.

Speyer (1972): Wolfgang Speyer, Fälschung, pseudepigraphische freie Erfindung und "echte religiöse Pseudepigraphie", in: K. von Fritz (ed.), Pseudepigrapha I. PseudopythagoricaLettres de Platon. Littérature pseudépigraphique juive. Entr. Ant. Class. 18, Genève-Vandoeuvres, 331-366.

Speyer (1991): Wolfgang Speyer, “Himmelsstimme”, in: RAC 15, 286-303.

Speyer (1994): Wolfgang Speyer, "Das Hören einer göttlichen Stimme. Zur Offenbarung und zu Heiligen Schriften im frühen Rom", in: Helmantica 45, 7-24.

Speyer (1995): Wolfgang Speyer, Religionsgeschichtliche Studien. Collectanea 15, Hildesheim, Zürich and New-York.

Speyer (2007): Wolfgang Speyer, Frühes Christentum im antiken Strahlungsfeld. Kleine Schriften III (WUNT 213), Tübingen.

Stella (2001): Francesco Stella (ed.), La scrittura infinita: Bibbia e poesia in età medievale e umanistica (Atti del convegno di Firenze 26-28 giugno 1997), Florence.

Thomassen (2004): Einar Thomassen, The Epiphany of Gnosis, in: Marinatos (ed.), 217-226.

Versnel (1987): Henk S. Versnel, What did Ancient Man see when He saw a God? Some Reflections on Greco-Roman Epiphany, in: van der Plas (ed.), 42-55.

Versnel (2011): Henk S. Versnel, Coping with the Gods. Wayward Readings in Greek Theology (RGRW 173), Leiden-Boston.

Vian (1990): Francis Vian (ed.), Nonnos de Panopolis. Les Dionysiaques, Tome IX: Chants XXV-XXIX, Paris.

Vian (1997): Francis Vian, "MAPTY乏 chez Nonnos de Panopolis: études de sémantique et de chronologie", in: RÉG 110, 143-160.

Weber (2000): Gregor Weber, Träume und Visionen in Prinzipat und Spätantike (Hist. 143), Stuttgart.

Whitaker (2015): Robin J. Whitaker, Ekphrasis, Vision, and Persuasion in the Book of Revelation (WUNT 2. 410), Tübingen, 641-674. 
